\title{
Prinsip Teologi Kristen Pendidikan Orang tua terhadap Anak di Era Revolusi Industri 4.0
}

\author{
Ruat Diana \\ Sekolah Tinggi Teologi Simpson, Ungaran, Jawa Tengah \\ rdianadarmawan@gmail.com
}

\begin{abstract}
This article discusses the role of parents in educating children in the industrial revolution era 4.0 based on Christian principles. The author analyzes several library sources both books and journals related to the topic of discussion. From the results of analysis of several literature sources, children's education is God's mandate given to parents. Parents have a role to educate them to become mature Christians. Spiritual maturity is the provision for children to face challenges in the era of the industrial revolution. Parents also play a role in educating about love and fairness. Love and fair moral values need to be instilled so that children can compete in a healthy manner in the era of the industrial revolution. The next role is to provide guidance to be able to live in groups. The development of digital media causes behavior changes that become increasingly individualistic, therefore children need to be educated to live in groups because humans cannot escape social life. Education in the era of industrial revolution was done by example. Children need a model that is a role model for living in the digital age.
\end{abstract}

Keywords: children education; Christian theology; digital era; parents; the era of 4.0

\begin{abstract}
Abstrak: Artikel ini memembasan tentang peran orang tua mendidik anak di era revolusi industri 4.0 berdasarkan prinsip Kristen. Penulis melakukan analisis beberapa sumber pustaka baik buku maupun jurnal yang terkait dengan topik bahasan. Dari hasil analisis beberapa sumber pustaka, pendidikan anak merupakan mandat Allah yang diberikan pada orang tua. Orang tua memiliki peran untuk mendidik mereka untuk menjadi orang Kristen dewasa. Kedewasaan rohani adalah bekal untuk anak-anak menghadapi tantangan di era revolusi industri. Orang tua juga berperan utnuk mendidik tentang kasih dan adil. Nilai moral kasih dan adil perlu ditanamkan agar anak-anak dapat bersaing secara sehat di era revolusi industri. Peran selanjutnya adalah memberikan bimbingan untuk dapat hidup dalam kelompok. Berkembangnya media digital menyebabkan perubahan perilaku yang menjadi semakin individualistis, oleh sebab itu anak-anak perlu dididik hidup dalam kelompok sebab manusia tidak dapat lepas dari kehidupan sosial. Pendidikan di era revolusi industri dilakukan melalui teladan. Anak-anak membutuhkan model yang menjadi teladan untuk hidup di era digital.
\end{abstract}

Kata Kunci: era digital; era industri 4.0; orang tua; pendidikan anak; teologi Kristen

\begin{tabular}{llll}
\hline Article History : & Received: 05-02-2019 & Revised: 03-04-2019 Accepted: 24-05-2019
\end{tabular}




\section{Pendahuluan}

Peran orang tua dalam mendidik anak sangat penting, baik dalam keluarga Kristen maupun keluarga non Kristen. Perkembangan zaman menjadi tantangan dalam mendidik anak, misalnya banyaknya media daring sebagai hasil perkembangan teknologi, menuntut tanggung jawab orang tua yang lebih baik untuk mendidik anak. Secara umum pendidikan Kristen dilakukan dalam empat konteks yaitu sekolah, keluarga, gereja dan masyarakat. ${ }^{1}$ Setiap anggota keluarga sangat berperan dalam mendidik anak, karena keluarga adalah komunitas terkecil yang memberi banyak pengaruh bagi masa depan anak tersebut. Keluarga merupakan lingkungan pertama bagi seorang anak untuk belajar, berinteraksi, dan mengenali banyak hal. Keluarga juga merupakan sebuah tempat bagi seorang anak untuk membawa pengalamannya, sehingga peran orang tua untuk mendidik anak mempunyai pergaruh besar bagi masa depan anak.

Dalam berbagai bidang kehidupan, dapat dilihat adanya peran didikan orang tua yang memberi pengaruh yang sangat kuat. Hubungan orang tua yang tidak harmonis akan membuat anak menjadi tegang dan mempengaruhi kondisi psikis mereka, oleh sebab itu perlu peran yang baik dari orang tua untuk mendidik anak. Untuk itu perlu dibahas tentang peran orang tua dalam mendidik anak. Kemudian di tengah persaingan dengan dunia maya, orang tua dituntut untuk menyelenggarakan pendidikan dalam konteks keluarga. Pratama mengungkapkan bahwa ada orang tua yang kalah bersaing dengan perkembangan maya yang terus berjalan seiring dengan perkembangan dengan teknologi. ${ }^{2}$ Oleh sebab itu, perlu upaya yang lebih signifikan dan jelas terkait pendidikan anak oleh orang tua. Memasuki era revolusi industri, peran orang tua dalam pendidikan anak semakin dibutuhkan, sebab perkembangan berbagai teknologi dapat menyebabkan lepasnya kontrol terhadap anak.

Tantangan krusial saat memasuki era revolusi industri adalah berkembangnya teknologi informasi yang mempengaruhi semua kelompok umur. Terhadap anak-anak, perkembangan teknologi menghasilkan perkembangan anak yang berbeda dengan perkembangan generasi sebelumnya, seperti masalah interaksi sosial yang berpindah dari interaksi langsung menjadi interaksi di dunia maya. Kemudian revolusi industri dapat menghasilkan persaingan antar manusia menjadi semakin tajam sehingga anakanak sebagai generasi penerus perlu dipersiapkan untuk hidup menghadapi tantangan tersebut. Revolusi industri diwarnai oleh kecerdasan buatan yang dimasukkan dalam mesin. Perkembangan tersebut tidak dapat ditolak tetapi anak-anak sebagai generasi baru yang akan menghadapi hasil dari perkembangan revolusi industri. Oleh sebab itu, orang tua perlu menjalankan fungsinya sebagai pendidik bagi anak-anaknya untuk menghadapi tantangan revolusi industri, serta menciptakan suasana rumah yang bersa-

${ }^{1}$ Iris V. Cully, Dinamika Pendidikan Kristen (Jakarta: BPK Gunung Mulia, 2009).

${ }^{2}$ Hellen Chou Pratama, Cyber Smart Parenting: Kiat Sukses Menghadapi dan Mengasuh GENERASI DIGITAL (Bandung: Visi Press, 2012). 
habat bagi anak-anak sehingga mereka dapat mulai membangun interaksi sosial dari lingkungan keluarga.

Penelitian yang relevan dengan penelitian ini adalah penelitian pustaka yang dilakukan oleh Ayang Emiyati. Emiyati lebih menyoroti soal mendisiplin anak menurut prinsip Kristen, sementara penelitian ini lebih menyoroti soal peran orang tua mendidik anak. Penelitian Emiyati menekankan pentingnya disiplin dalam pendidikan anak, hanya ia menekankan perlu minimalisir kekerasan. Walau demikian Emiyati menyinggung adanya perintah Alkitab untuk melakukan disiplin dengan tegas. ${ }^{3}$ Penelitian lain yang membahas tentang pendidikan anak dilakukan oleh Wenas dan Darmawan yang membahas pendidikan anak dari perspektif Alkitab. Penelitian yang berjudul "Siginifikasi Pendidikan Anak Dalam Perspektif Alkitab" dilakukan oleh Wenas dan Darmawan lebih menekankan pembahasan beberapa teks Alkitab. Dari penelitian Wenas dan Darmawan tampak jika ada tugas yang mendesak dan penting untuk melaksanakan pendidikan anak dari sudut pandang Alkitab. ${ }^{4}$ Penelitian terkait dengan isu pendidikan Kristen di era cyber adalah penelitian yang dilakukan oleh Wadi dan Selfina. Wadi dan Selfina dalam penelitiannya tentang peran orang tua sebagai keluarga cyber smart dalam mengajarkan pendidikan Kristen pada remaja, mengungkapkan bahwa ada peran orang tua dalam mengajarkan firman Tuhan kepada remaja, kemudian mendidik anak-anak mereka, menjalankan disiplin, lalu menjadi teladan bagi remaja dan menciptakan keluarga cyber smart. ${ }^{5}$ Kemudian Watt dan Palar juga melakukan penelitian terkait dengan peran orang tua dalam pendidikan dalam keluarga. Watt dan Palar menekankan perlu tindakan preventif orang tua menghadapi pergaulan bebas anak mereka. ${ }^{6}$ Dari beberapa penelitian di atas tampak jika pendidikan anak juga dilakukan dalam keluarga dan perlu peran orang tua dalam mendidik anak. Mengingat orang tua memiliki peran penting bagi pembentukan pribadi anak, maka perlu sebuah paparan yang jelas tentang peran orang tua dalam mendidik anak.

Sebuah tindakan praktis dalam kehidupan Kristen dimulai dengan prinsip teologi Kristen yang jelas. Teologi menjadi fondasi pikir yang kemudian memengaruhi tindakan praktis. Dalam penelitian yang dilakukan oleh Panggabean, fondasi pendidikan Kristen

\footnotetext{
${ }^{3}$ Ayang Emiyati, "Mendisiplin Anak Menurut Prinsip Kristen," Evangelikal: Jurnal Teologi Injili dan Pembinaan Warga Jemaat 2, no. 2 (2018): 147-156.

${ }^{4}$ Maria Lidya Wenas and I Putu Ayub Darmawan, "Signifikansi Pendidikan Anak Dalam Perspektif Alkitab," Evangelikal: Jurnal Teologi Injili dan Pembinaan Warga Jemaat 1, no. 2 (2017), http://journal.sttsimpson.ac.id/index.php/EJTI.

${ }^{5}$ Elsyana Nelce Wadi and Elisabet Selfina, "Peran Orang Tua Sebagai Keluarga Cyber Smart Dalam Mengajarkan Pendidikan Kristen Pada Remaja GKII Ebenhaezer Sentani Jayapura Papua," Jurnal Jaffray 14, no. 1 (March 2016): 77-92.

${ }^{6}$ Esti Christina Watt and Ivone Bonyadone Palar, "Tindakan Preventif Orang Tua Terhadap Pergaulan Bebas di Kalangan Remaja Kristen Suatu Pengamatan di GKII Efata Airmadi di Manado," Jurnal Jaffray 10, no. 2 (October 2012): 140-156.
} 
dikonstruksi melalui sebuah konstruksi teologi. ${ }^{7}$ Oleh sebab itu, sebuah uraian tindakan praktis dalam kehidupan Kristen harus disusun dengan menggunakan prinsip teologi yang juga disusun dengan prinsip Alkitab. Sebagai contoh penelitian yang dilakukan oleh Kapojos dan Wijaya yang melakukan penelitian pada teks Alkitab, kemudian mengemukakan sebuah implikasi teologis dan praktis. ${ }^{8}$ Dari penelitian tersebut tampak jika aspek praktis dilandasi oleh kerangka teologis yang jelas. Demikian pula penelitian Wenas dan Darmawan yang lebih dahulu memaparkan uraian pendidikan yang berdasarkan prinsip Alkitab, kemudian dapat dikemukakan sebuah implikasi praktisnya. Dalam penelitiannya, Wenas dan Darmawan melakukan analisis terha-dap beberapa teks Alkitab, kemudian mengemukakan tentang pendidikan anak. ${ }^{9}$ Oleh sebab itu, penelitian ini dilakukan untuk memaparkan peran orang tua dalam mendidik anak berdasarkan prinsip teologi Kristen.

Berdasarkan latar belakang di atas, maka dikemukakan rumusan masalah "Bagaimana prinsip teologi Kristen pendidikan orang tua terhadap anak di era revolusi industri 4.0? Tujuan penulisan artikel ini adalah untuk mengelaborasi secara deskriptif prinsip teologi Kristen pendidikan orang tua terhadap anak di era revolusi industri 4.0.

\section{Metode Penelitian}

Ini merupakan penelitian kualitatif yang menggunakan sumber-sumber literatur sebagai data yang kemudian dianalisis dengan mencermati kesamaan, kerterkaitan, maupun kontra terhadap konsep yang dibahas. Penulis menggunakan beberapa sumber dari buku yang ditulis oleh teolog Kristen di Indonesia yang membahas tentang pendidikan anak. Sumber pustaka dari teolog Selain itu, penulis juga menggunakan sumber-sumber pustaka yang terbit di beberapa jurnal dan terkait dengan topik bahasan. Karena penelitian ini merupakan sebuah kajian yang mengangkat topik pendidikan dan teologi Kristen, maka penulis mengedepankan penggunaan sumber-sumber dari teolog Kristen, akademisi pendidikan Kristen, maupun praktisi pendidikan Kristen. Penulis melakukan pengamatan terhadap perubahan dan perilaku manusia yang terjadi di era revolusi industry. Perkembangan yang terjadi di era revolusi industri penulis cermati juga dari berbagai sumber pustaka yang membahas topik tersebut.

Hasil analisis terhadap beberapa sumber pustaka kemudian disusun secara deskriptif dan sistematis tematik. Penyusunan tema juga terkait dengan konsep yang telah terbangun pada penulis. Penyajian secara sistematis tematik dilakukan mengelompokkan dan mendiskusikan data-data yang telah dikumpulkan dari berbagai sumber

\footnotetext{
7Justice Zeni and Zari Panggabean, "Pendekatan Praksis-Teologis Dalam Fondasi Pendidikan Kristiani," KURIOS (Jurnal Teologi dan Pendidikan Agama Kristen) 4, no. 2 (2018): 167-181, http://www.sttpb.ac.id/e-journal/index.php/kurios/article/view/81.

8Shintia Maria Kapojos and Hengki Wijaya, "Perwujudan Kasih Setia Allah Terhadap Kesetiaan Rut," Evangelikal: Jurnal Teologi Injili dan Pembinaan Warga Jemaat 2, no. 2 (July 2018): 99-104.

9Maria Lidya Wenas and Darmawan, "Signifikansi Pendidikan Anak Dalam Perspektif Alkitab."
} 
sesuai temanya. Sumber-sumber data yang telah dikumpulkan penulis analisis secara komprehensif sehingga dihasilkan suatu simpulan sesuai dengan temanya. ${ }^{10}$

\section{Hasil dan Pembahasan}

\section{Pendidikan Anak Sebagai Mandat Allah}

Stephen Tong memaparkan bahwa orang tua merupakan wakil Allah yang memiliki satu tanggapan yang berbeda dengan orang non Kristen. Tong menekankan bahwa orang tua adalah wakil Allah di hadapan manusia dan ini suatu prinsip penting. Seorang Kristen diharapkan untuk sadar dan ingat jika ia memiliki tugas untuk mendidik anak dan menjadi wakil Allah bagi anak. ${ }^{11}$ Oleh karena orang tua Kristen merupakan wakil Allah dalam mendidik anak maka mendidik anak dilakukan dengan berhati-hati dan penuh tanggung jawab. Oleh sebab itu, orang tua Kristen harus menanamkan dalam hati dan pikirannya suatu konsep bahwa orang tua adalah wakil Tuhan.

Ulangan 6:6-7 menegaskan tanggung jawab orang tua dalam mendidik anaknya dengan tekun, "Apa yang ku perintahkan kepadamu pada hari ini haruslah engkau perhatikan. Haruslah engkau mengajarkannya berulang-ulang kepada anak-anakmu dan membicarakannya apa bila engkau duduk di rumahmu, apabila engkau sedang dalam perjalanan, apabila engkau berbaring dan apabila engkau bangun." Demikian pula dalam Mazmur 78:5,6 ditekankan bahwa ada tugas untuk mendidik anak-anak sehingga dapat mengenal perintah/taurat Allah dan mendidik di jalan yang benar. ${ }^{12}$ Wenas dan Darmawan menekankan bahwa berdasarkan teks Ulangan 6:7-9 ada tugas orang tua untuk mengajarkan iman dengan tekun kepada anak-anak mereka (ay. 7-9). Demikian pula berdasarkan Mazmur 78:5-6 ada tugas orang tua untuk mengajarkan taurat Tuhan pada anak-anak sehingga mereka dapat hidup dengan taat. Lalu, mengacu pada Keluaran 12:24-27, Wenas dan Darmawan mengungkapkan bahwa Allah memberikan pada orang tua kuasa untuk mendidik anak-anak mereka, kuasa tersebut diberikan agar orang tua mendidik anak-anak untuk memahami karya Allah dalam kehidupan mereka. ${ }^{13}$ Dari berapa paparan di atas tampak ada mandat Allah untuk mendidik anak, agar mereka dapat memahami karya Allah. Tugas mengajar anak secara terus-menerus akan keyakinan iman Kristen diberikan Allah kepada orang tua, sehingga anak menjadi taat.

\section{Pendidikan Orang tua terhadap Anak di Era Revolusi Industri Mendidik Untuk Pendewasaan Rohani Anak}

Menghadapi perkembangan yang terjadi di era revolusi industri yang penuh dengan berbagai tantangan, kedewasaan secara rohani menjadi sangat penting. Dengan kehidupan

\footnotetext{
${ }^{10}$ Karnawati Karnawati and Priyantoro Widodo, "Landasan Filsafat Antropologi-Teologis Dalam Pengembangan Kurikulum Pendidikan Kristen," Evangelikal: Jurnal Teologi Injili dan Pembinaan Warga Jemaat 3, no. 1 (January 2019): 82-89.

11Stephen Tong, Membesarkan Anak Dalam Tuhan (Surabaya: Momentum, 2015).

12Ferry Yang, Pendidikan Kristen (Surabaya: Momentum, 2018).

13Maria Lidya Wenas and Darmawan, "Signifikansi Pendidikan Anak Dalam Perspektif Alkitab."
} 
Kristen yang dewasa, anak-anak dapat memiliki bekal hidup dalam menghadapi perubahan. Perubahan teknologi dapat menyebabkan anak tidak siap menghadapi perubahan tersebut, sehingga mereka perlu berusaha menyesuaikan diri menghadapi perubahan tersebut. Untuk dapat menyesuaikan diri, anak-anak perlu didikan orang tua sehingga mereka dapat beradaptasi menghadapi perubahan. ${ }^{14}$

Dalam konteks pendidikan dalam keluarga, orang tua berperan untuk mendidik anak agar menjadi orang Kristen yang dewasa. Hal itu relevan dengan tujuan pendidikan Kristen yang dikemukakan oleh Graendrof. Menurus Graendrof, tujuan pendidikan Kristen adalah pendewasaan setiap orang Kristen sehingga dapat menjadi manusia Kristen yang dewasa. ${ }^{15}$ Kemudian Pangabean dalam jurnalnya mengungkapkan bahwa pendidikan Kristen merupakan sebuah proses di mana di dalamnya ada pelatihan, pengajaran, dan pemeliharaan, yang bertujuan untuk memampukan seseorang menjadi bertumbuh dan dewasa dalam iman. ${ }^{16}$ Tujuan pendidikan Kristen yang dikemukakan oleh Graendrof dan Pangabean juga sejalan dengan teks Matius 28:19-20. Teks Matius 28:19-20 memberi penekanan juga pada adanya usaha untuk mendewasakan setiap orang Kristen yang adalah murid Kristus. Indikator kedewasaan orang Kristen berdasarkan Matius 28:19-20 adalah, orang Kristen melakukan apa yang diperintahkan Allah. Perhatikan bagian nas ini "...ajarlah mereka melakukan segala sesuatu yang telah Kuperintahkan kepadamu." Hal itu menunjukkan secara umum, ada tugas pendidikan Kristen untuk melakukan pendewasaan.

Mendidik anak untuk mendewasakannya, juga merupakan sebuah implementasi dari teologi pernikahan dan keluarga. Sebagai implementasi teologi pernikahan dan keluarga, Tanusaputra juga mengungkapkan bahwa orang tua perlu menciptakan lingkungan keluarga yang memungkinkan anak-anak dapat hidup bertumbuh dan menjadi dewasa. ${ }^{17}$ Terciptanya lingkungan keluarga yang bertumbuh dan menjadi dewasa merupakan tanggung jawab orang tua. Dengan demikian jelas bahwa ada peran orang tua untuk melakukan pendidikan yang mendewasakan dalam konteks keluarga.

Untuk menjadi dewasa dalam Kristus, ada suatu proses pertumbuhan rohani yang terus terjadi secara berkelanjutan. Gooddall dan Gooddall mengungkapkan untuk membantu anak-anak bertumbuh secara rohani beberapa langkah berikut dapat diambil orang tua: a) Persembahkan anak-anak kepada Allah sedini mungkin dalam hidup mereka (1 Sam. 1:24-28, Luk. 2:22); b) Ajar anak-anak mengasihi Tuhan dan berpaling

\footnotetext{
${ }^{14}$ Etistika Yuni Wijaya, Dwi Agus Sudjimat, and Amat Nyoto, "Transformasi Pendidikan Abad 221 Sebagai Tuntutan Pengembangan Sumber Daya Manusia di Era Global," in Prosiding Seminar Nasional Pendidikan Matematika 2016 - Universitas Kanjuruhan Malang, vol. 1 (Malang: Universitas Kanjuruhan Malang, 2016), 263-278.

${ }^{15}$ Werner C. Graendorf, Introduction to Biblical Christian Education (Chicago: Moody Pub, 1981).

${ }^{16}$ Justice Zeni and Zari Panggabean, "Pendekatan Praksis-Teologis Dalam Fondasi Pendidikan Kristiani," KURIOS (Jurnal Teologi dan Pendidikan Agama Kristen) 4, no. 2 (2018): 167-181, http://www.sttpb.ac.id/e-journal/index.php/kurios/article/view/81.

${ }^{17}$ Daniel Tanusaputra, "Teologi Pernikahan dan Keluarga," Veritas: Jurnal Teologi dan Pelayanan 6, no. 1 (2005): 73-101.
} 
dari dosa. Bantu mereka memahami akibat-akibat dosa dalam hidup ini dan penghakiman terakhir. Tekankan perhatian Allah kepada anak-anak kecil; c) Asuhlah anak-anak sehingga mereka akan bertumbuh mengasihi Allah (Ef. 6:4). Setiap hari penuh dengan kesemapatan untuk menagajar hukum-hukum Allah; d) Buatlah agar belajar tentang Allah itu menyenangkan dengan mengunakan buku-buku berisi cerita-cerita Alkitab yang bergambar; e) Ajarlah anak-anak menaati orang tua. Tunjukan pada anak-anak bahwa mereka patut menghormati dan mentaati oarang tua. Ini mempersiap-kan mereka untuk menghormati dan mentaati Allah (Ibr. 12:7-11); f) Bawalah anak-anak ke gereja yang mengajarkan dan mentaati Firman Allah. ${ }^{18}$

Dengan kedewasaan secara rohani, anak-anak dapat memahami bagaimana mereka seharusnya hidup, mereka memahami mana yang boleh mereka lakukan dan tidak boleh mereka lakukan. Dengan mendidik anak memiliki kedewasaan secara rohani, orang tua juga secara tidak langsung mendidik anak-anaknya hidup dengan etika Kristen yang pada akhirnya mereka dapat mengambil keputusan etis dalam hidup mereka. Bagi Wenas dan Darmawan, pendewasaan rohani anak penting untuk menolong mereka dapat hidup menghadapi perubahan zaman. ${ }^{19}$ Oleh sebab itu, orang tua perlu meningkatkan perannya dalam melakukan pendidikan untuk pendewasaan rohani anak.

\section{Mendidik Tentang Kasih dan Adil}

Revolusi industri menimbulkan terjadinya persaingan dalam berbagai bidang. Hal itu membentuk pula perilaku manusia yang menjadikannya hidup dalam persaingan yang ketat. Revolusi industri menghasilkan tantangan sosial berupa terjadinya perubahan nilai-nilai sosial. Perubahan nilai-nilai sosial tersebut menuntut kemampuan untuk mentransfer pengetahuan, keterampilan memimpin, dan kesiapan untuk menghadapi rotasi pekerjaan. ${ }^{20}$ Revolusi industri juga menyebabkan semakin berkurangnya peran manusia. Kondisi tersebut menimbulkan persaingan yang semakin ketat antar pencari kerja maupun persaingan pengelola industri. ${ }^{21}$ Riyana sebagaiama diberitakan oleh Ibrahim menjelaskan bahwa era revolusi industri dapat mengakibatkan menghilangnya 1 sampai 1,5 juta pekerjaan dalam kurun waktu 10 tahun.

Kondisi tersebut dapat menimbulkan persaingan yang tidak sehat jika tidak ada antisipasi melalui pendidikan. ${ }^{22}$ Salah satu kunci penting dalam menghadapi revolusi industri adalah dengan kolaborasi, sehingga akhirnya dapat melewati disrupsi teknologi. Untuk menciptakan perilaku bersaing yang sehat dan siap berkolaborasi, maka manusia perlu memegang nilai-nilai moral yang benar. Era revolusi industri yang memunculkan

\footnotetext{
${ }^{18}$ Wayde I. Gooddall and Rosalyn R. Gooddall, Marriage \& Family (Malang: Gandum Mas, 2010). ${ }^{19}$ Maria Lidya Wenas and Darmawan, "Signifikansi Pendidikan Anak Dalam Perspektif Alkitab."

${ }^{20}$ Tantangan dan Peluang Revolusi Industri 4.0, n.d.

21“Universitas Gadjah Mada: Tantangan Manusia Di Era Revolusi Industri 4.0.” Malang."

${ }^{22}$ Said Maulana Ibrahim, "Tantangan Pendidikan Era Revolusi Industri 4.0 | Universitas Negeri
} 
persaingan dan kemitraan, membutuhkan generasi yang memiliki sikap dan rasa keadilan sosial. Itu sebabnya nilai adil harus telah ditanamkan melalui pendidikan pada anakanak. $^{23}$

Dalam kekristenan, nilai-nilai moralnya adalah kasih dan adil. Nilai moral tersebut sejalan dengan prinsip Alkitab. Orang tua perlu mengajarkan nilai tersebut, sehingga anak-anak dapat memiliki nilai moral yang sesuai dengan prinsip Alkitab. Tanusaputra, mengacu pada Efesus 6:4 dan Kolose 3:21 menekankan penting memberi teladan untuk bersikap kasih dan adil, sehingga dapat mendidik anak untuk juga hidup dengan kasih dan adil. ${ }^{24}$ Alkitab dalam Ulangan 6:5 menunjukkan jika ada tugas orang tua untuk mendidik anak-anaknya mengasihi TUHAN, Allah. Dalam teks Ulangan 6:5 dituliskan demikian "Kasihilah TUHAN, Allahmu, dengan segenap hatimu dan dengan segenap jiwamu dan dengan segenap kekuatanmu." Wenas dan Darmawan mengungkapkan bahwa tugas pendidikan dalam Ulangan 6:5 harus dilakukan dengan tekun, secara intensif dalam berbagai kesempatan. ${ }^{25}$ Dengan demikian peran orang tua dalam mendidik anak adalah mendidiknya tentang kasih dan adil.

Anak-anak perlu belajar bagaimana bersikap mengasihi dan berikap adil. Hal itu dapat diajarkan melalui teladan orang tua yang mengasihi anak dengan sikap yang adil. Apabila ada ketidakadilan dalam kehidupan keluarga, anak dapat merasa tidak dicintai dalam keluarga. Dalam menghadapi revolusi industri, setiap orang Kristen dituntut hidup dengan nilai-nilai moral yang baik. Anak-anak sebagai generasi yang hidup dan mengalami dampak revolusi industri perlu didik dengan nilai-nilai moral Kristen tersebut, sehingga mereka dapat menampilkan hidup yang adil tetapi juga mengasihi orang lain.

\section{Membimbing Anak Hidup dalam Kelompok}

Perkembangan teknologi yang cukup pesan menciptakan kemudahan dalam berbagai bidang. Kondisi tersebut juga berdampak pada kehidupan interaksi sosial yang menjadi semakin rendah. Hadirnya media sosial, menciptakan kehidupan sosial yang hadir dalam ketidak hadiran, dalam arti bahwa ada interaksi antar individu tetapi tidak dalam sebuah pertemuan yang saling berhadapan. Kondisi tersebut, yang menurut Tanuwidjaja, kemudian berdampak pada terjadinya mabuk teknologi. Mabuk teknologi menyebabkan rendahnya interaksi antar individu. ${ }^{26}$ Contoh kasus sebagai dampak dari mabuk teknologi adalah terjadinya pubing. Mabuk teknologi juga dapat berdampak pada terjadinya hilangnya kesadaran akan fungsi sosial setiap orang. Oleh karena kondisi

\footnotetext{
${ }^{23}$ Memandang Revolusi Industri \& Dialog Pendidikan Karakter Di Perguruan Tinggi Indonesia (Jakarta: Direktorat Pembelajaran Direktorat Jenderal Pembelajaran dan Kemahasiswaan Kementerian Riset, Teknologi, dan Pendidikan Tinggi, 2017).

24 Tanusaputra, "Teologi Pernikahan dan Keluarga."

${ }^{25}$ Maria Lidya Wenas and Darmawan, "Signifikansi Pendidikan Anak Dalam Perspektif Alkitab."

26Sundoro Tanuwidjaja, "Janji Manis Teknologi," in Melaksanakan Amanat Agung Di Abad 21 (Ungaran: Sekolah Tinggi Teologi Simpson, 2017), 65-74.
} 
tersebut, perlu sebuah usaha nyata yang memersiapkan anak-anak hidup dalam perkembangan teknologi salah satunya dengan melaksanakan pendidikan yang membimbing anak hidup dalam kelompok.

Peran orang tua mendidik anak adalah memberikan bimbingan agar mereka tahu bagaimana hidup dalam kelompok. Ketika anak melakukan kesalahan, yang dibutuhkan bukan hanya teguran dan hukuman, melainkan nasihat. Setiawani menjelaskan bahwa bimbingan terhadap setiap anak harus berbeda karena tidak tidak ada dua anak yang sama, kemudian orang tua memberikan bantuan pada anak untuk memperoleh lebih banyak pengalaman yang berhasil dilakukan dalam kelompok. Selain itu, menurut Setiawani, orang tua juga memberikan bimbingan untuk membantu anak untuk mengenal bagaimana bisa dengan aman hidup di dalam masyarakat dan belajar bagaimana mendirikan hubungan antar individu. ${ }^{27}$ Minimnya interaksi antar individu yang terjadi sebagai dampak perkembangan teknologi perlu disikapi dengan memberikan bagaimana hidup dalam kelompok sehingga tidak menjadi manusia yang individualistik. Handitya menjelaskan bahwa salah satu dampak dari disrupsi teknologi adalah menguatkan perilaku individualistik. ${ }^{28}$ Demikian pula dikemukakan oleh Armawi bahwa perkembangan teknologi menghasilkan perubahan tata nilai dan perilaku manusia, salah satunya adalah perilaku manusia yang semakin individualis. ${ }^{29}$ Walau demikian, orang tua harus menyadari bahwa manusia tidak dapat hidup lepas dari komunitas sosial. Dengan demikian pendidikan bagaimana anak hidup dalam kelompok penting untuk dilakukan sehingga anak tidak hidup semakin individualistis.

Dalam Alkitab pendidikan terhadap anak juga menekankan pada bagaimana mereka hidup dalam komunitasnya. Interaksi jemaat mula-mula sebagaimana dicatat dalam Kisah Para Rasul menunjukkan bahwa ada perilaku manusia yang hidup dalam kelompok, termasuk anak-anak sebagai bagian dari komintas Kristen pada waktu itu. Kehidupan Kristen merupakan kehidupan yang hidup dalam komunitas. Sebuah komunitas bisa terdiri dari berbagai macam budaya, bahasa, karakter dan konsep. Bila mencermati teks dalam Matius 28:19-20 maka murid Kristus adalah orang-orang dari berbagai suku bangsa, itu artinya setiap anak dari keluarga Kristen akan hidup dalam kelompok yang multiketnis. Itu sebabnya orang tua berperan untuk membimbing anaknya bagaimana hidup dalam kelompok. Kelompok menjadi tempat bagi setiap orang Kristen bertumbuh, karena adanya interaksi dan berbagi cerita tentang kasih Allah. Boiliu mengungkapkan bahwa selain mengarahkan anak pada dimensi hubungan

\footnotetext{
27M. G. Setiawani, Menerobos Dunia Anak (Bandung: Kalam Hidup, 1993).

${ }^{28}$ Binov Handitya, "Peran Pendidikan Dalam Membangun Moral Bangsa Di Era Disrupsi," in Seminar Nasional PKn UNNES, vol. 2, 2018, 41-52.

${ }^{29}$ Armaidy Armawi, "Dari Konsumerisme ke Konsumtivisme (Dalam Perpektif Sejarah Filsafat Barat)," Jurnal Filsafat 17, no. 3 (March 2017): 314-323.
} 
anak dengan Tuhan ("aku dan Tuhanku"), ada tugas untuk mengarahkan anak pada hubungan dengan orang lain ("aku dan yang lain"). ${ }^{30}$

Daniel Ronda menjelaskan bahwa perkembangan teknologi di era revolusi industri memungkinkan terjadinya perubahan dalam kehidupan orang Kristen termasuk dalam kehidupan bergereja. Menurut Ronda, perkembangan teknologi memungkinkan terjadinya kebaktian secara online, tetapi sentuhan kasih dan interaksi antar individu masih dibutuhkan dan masing sangat penting. ${ }^{31}$ Mencermati pernyataan yang dikemukakan oleh Ronda, maka jelas jika setiap orang perlu memahami bagaimana hidup dalam kelompok. Demikian pula anak-anak sebagai generasi yang hidup di era revolusi industri perlu memahami bagaimana mereka hidup dalam kelompok masyarakat, dan orang tua berperan penting untuk mendidik anak-anak dapat hidup dalam kelompok.

Langkah praktis untuk mengajarkan anak hidup dalam kelompok adalah 1) Menentukan aturan dalam bermedia digital, sehingga memberi ruang pada anak untuk berinteraksi dengan orang lain; 2) Melibatkan anak-anak dalam kehidupan sosial masyarakat, sehingga anak-anak menyadari pentingnya kehidupan sosial; 3) Melibatkan anak-anak dalam kegiatan komunitas iman, agar mereka membiasakan diri bergaul dengan orang lain dan bertumbuh bersama dalam komunitas iman; 4) Orang tua membangun suasana rumah yang nyaman bagi anak untuk berinteraksi dengan seluruh anggota keluarga. Setiap anggota keluarga adalah kelompok kecil yang memiliki karakter dan kepribadian berbeda, situasi tersebut adalah peluang yang dapat digunakan untuk mendidik anak hidup dalam kelompok.

\section{Melaksanakan Pendidikan Dengan Teladan}

Prinsip pendidikan yang penting untuk terus dilaksanakan adalah memberikan teladan. Cara terbaik mendidik anak berkarakter baik ialah melalui teladan orang tua sendiri. Dalam lingkungan keluarga, anak akan selalu mencermati perilaku orang tua mereka baik dalam hal bertutur dan berprilaku. Apabila ada perilaku orang tua yang kasar dan egois, maka akan sulit untuk mendidik anak bersifat baik dan suka berbagi rasa dengan orang lain. ${ }^{32}$ Apabila orang tua menyuruh anak berbohong, maka orang tua sedang menciptakan suatu generasi yang tidak jujur. Anak bisanya cepat menangkap dan menyadari bahwa perkataan dan perbuatan orang tuanya tidak seiring. Karakter yang perlu dibina itu adalah kejujuran, hormat, kasih, semangat, taat, tanggung jawab, menghormati orang dewasa. Bahkan perlu adanya tuntutan hidup Rohani seperti iman, kasih, kesalehan, dan doa dan membaca Alkitab. Teladan kehidupan seperti ini harus selalu diteladani anak.

${ }^{30}$ N. I. Boiliu, “Misi Pendidikan Agama Kristen Dan Problem Moralitas Anak," Regula Fidei 1, no. 1 (2016): 115-140.

31Daniel Ronda, "Kepemimpinan Kristen di Era Disrupsi Teknologi," Evangelikal: Jurnal Teologi Injili dan Pembinaan Warga Jemaat 3, no. 1 (January 2019): 1-8.

32Setiawani, Menerobos Dunia Anak. 
Di era revolusi industri, perkembangan teknologi menimbulkan perumbahan perilaku manusia. Penggunaan gadget secara berlebih menimbulkan masalah dalam interaksi antar manusia, termasuk juga pada anak-anak. Pada observasi yang penulis lakukan pada sebuah PAUD di Ungaran, penulis mencermati adanya perilaku anak yang bermain menggunakan handphone orang tuanya sebelum masuk ke kelas. Perilaku tersebut tampaknya dicontoh dari orang tuanya. Dari pengamatan penulis, saat orang tua menunggu anaknya di sekolah, orang tua lebih memilih untuk bermain game di handphonenya. Dari kasus tersebut, tampak jika orang tua memiliki peran sebagai teladan bagi anakanaknya. Oleh sebab itu, orang tua perlu menjalankan fungsinya sebagai teladan sehingga dapat menjalankan pendidikan yang baik dalam konteks keluarga di era revolusi industri.

Perkembangan teknologi juga menimbulkan perilaku, dimana sikap anak pada orang tua menjadi berubah. Oleh sebab itu, peran orang tua adalah mengajarkan mereka melalui teladan bagaimana menghormati orang tua. Wenas dan Darmawan memberikan penjelasan pada teks Efesus 6:1-4 bahwa orang tua perlu mendidik anak mereka agar memiliki sikap menghormati orang tua. Penekanan lebih diberikan pada ayah yang harus menjaga otoritas keluarga. ${ }^{33}$ Oleh sebab itu orang tua memberikan teladan dengan menghormati orang tua (kakek dan nenek) mereka.

Keteladanan juga diperlukan terkait dengan penggunaan media digital. Orang tua sebagai model yang dilihat setiap hari dan ditiru anak-anak, perlu memberi teladan dalam bermedia digital. Anak-anak usia dini umumnya telah mampu mengoperasikan media digital, hanya mereka belum memiliki kemampuan untuk menggunakan media digital secara baik dan benar. Dalam pendidikan terhadap anak, orang tua adalah model yang memberikan teladan bermedia digital secara baik dan benar. Sebagai contoh, orang tua menjadi teladan yang membatasi penggunaan media digital ketika berinteraksi langsung dengan orang lain. Perilaku tersebut dapat mendidik anak untuk tidak melakukan pubing.

\section{Kesimpulan}

Dari hasil analisis dan pembahasan, penulis menyimpulkan bahwa ada mandat Allah bagi orang tua untuk melaksanakan pendidikan bagi anak-anak. Untuk menjalankan mandat tersebut ada beberapa peran orang tua, yaitu: a) Orang tua berperan untuk mendidik anak-anaknya menjadi orang Kristen yang dewasa sehingga terus bertumbuh secara rohani. Kedewasaan rohani akan memampukan anak-anak menghadapi perkembangan yang terjadi sebagai dampak dari revolusi industri; b) Revolusi industri menimbulkan persaingan yang ketat, tetapi dapat dihadapi dengan adanya kolaborasi. Untuk dapat hidup berkolaborasi, manusia harus hidup dengan nilai moral yang benar,

33Maria Lidya Wenas and Darmawan, "Signifikansi Pendidikan Anak Dalam Perspektif Alkitab." 
dan bagi anak-anak Kristen mereka perlu memiliki nilai moral adil dan kasih; c) Orang tua bertanggung jawab untuk membimbing anak hidup dalam kelompok. Revolusi industri menciptakan perilaku individualitis, sehingga perlu dihadapi dengan memberikan pendidikan pada anak-anak tentang bagaimana hidup dalam kelompok; d) Orang tua melaksanakan pendidikan anak dengan keteladanan. Teladan hidup orang tua pada anak memiliki peran penting dalam membentuk perilaku anak, seperti bagaimana menghormati orang tua.

\section{Referensi}

Armawi, Armaidy. "Dari Konsumerisme ke Konsumtivisme (Dalam Perpektif Sejarah Filsafat Barat)." Jurnal Filsafat 17, no. 3 (17 Maret 2017): 314-23. https://doi.org/10.22146/jf.23090.

Boiliu, N. I. "Misi Pendidikan Agama Kristen Dan Problem Moralitas Anak." Regula Fidei 1, no. 1 (2016): 115-40.

Cully, Iris V. Dinamika Pendidikan Kristen. Jakarta: BPK Gunung Mulia, 2009.

Emiyati, Ayang. "Mendidik Anak Menurut Prinsip Kristen." Evangelikal: Jurnal Teologi Injili dan Pembinaan Warga Jemaat 2, no. 2 (31 Juli 2018): 147-56.

Gooddall, Wayde I., dan Rosalyn R. Gooddall. Marriage \& Family. Malang: Gandum Mas, 2010.

Graendorf, Werner C. Introduction to Biblical Christian Education. Chicago: Moody Pub, 1981.

Handitya, Binov. "Peran Pendidikan Dalam Membangun Moral Bangsa Di Era Disrupsi." Dalam Seminar Nasional PKn UNNES, 2:41-52, 2018. http://proceedings.id/index.php/pkn/article/view/724.

Ibrahim, Said Maulana. "Tantangan Pendidikan Era Revolusi Industri 4.0 | Universitas Negeri Malang." Diakses 7 Maret 2019.

https://um.ac.id/content/page/2/2018/11/tantangan-pendidikan-era-revolusiindustri-4-0.

Kapojos, Shintia Maria, dan Hengki Wijaya. "Perwujudan Kasih Setia Allah Terhadap Kesetiaan Rut." Evangelikal: Jurnal Teologi Injili dan Pembinaan Warga Jemaat 2, no. 2 (31 Juli 2018): 99-104.

Karnawati, Karnawati, dan Priyantoro Widodo. "Landasan Filsafat Antropologi-Teologis Dalam Pengembangan Kurikulum Pendidikan Kristen.” Evangelikal: Jurnal Teologi Injili dan Pembinaan Warga Jemaat 3, no. 1 (30 Januari 2019): 82-89.

Memandang Revolusi Industri \& Dialog Pendidikan Karakter di Perguruan Tinggi Indonesia. Jakarta: Direktorat Pembelajaran Direktorat Jenderal Pembelajaran dan Kemahasiswaan Kementerian Riset, Teknologi, dan Pendidikan Tinggi, 2017.

Panggabean, Justice dan Zari, Zeni. "Pendekatan Praksis-Teologis dalam Fondasi Pendidikan Kristiani." Kurios 4, no. 2 (31 Oktober 2018): 167-81. https://doi.org/10.30995/kur.v4i2.81.

Pratama, Hellen Chou. Cyber Smart Parenting: Kiat Sukses Menghadapi dan Mengasuh GENERASI DIGITAL. Bandung: Visi Press, 2012.

Ronda, Daniel. "Kepemimpinan Kristen di Era Disrupsi Teknologi." Evangelikal: Jurnal Teologi Injili dan Pembinaan Warga Jemaat 3, no. 1 (30 Januari 2019): 1-8.

Setiawani, M. G. Menerobos dunia Anak. Bandung: Kalam Hidup, 1993.

“Tantangan dan Peluang Revolusi Industri 4.0." Diakses 7 Maret 2019. https://www.silabus.web.id/tantangan-dan-peluang-revolusi-industri-4-0/. 
Tanusaputra, Daniel. "Teologi Pernikahan dan Keluarga." Veritas: Jurnal Teologi dan Pelayanan 6, no. 1 (2005): 73-101.

Tanuwidjaja, Sundoro. “Janji Manis Teknologi.” Dalam Melaksanakan Amanat Agung di Abad 21, 65-74. Ungaran: Sekolah Tinggi Teologi Simpson, 2017.

Tong, Stephen. Membesarkan Anak Dalam Tuhan. Surabaya: Momentum, 2015.

“Universitas Gadjah Mada: Tantangan Manusia Di Era Revolusi Industri 4.0.” Diakses 7 Maret 2019. http://ugm.ac.id/id/berita/17203tantangan.manusia.di.era.revolusi.industri.40.

Wadi, Elsyana Nelce, dan Elisabet Selfina. "Peran Orang Tua Sebagai Keluarga Cyber Smart Dalam Mengajarkan Pendidikan Kristen Pada Remaja GKII Ebenhaezer Sentani Jayapura Papua." Jurnal Jaffray 14, no. 1 (14 Maret 2016): 77-92. https://doi.org/10.25278/jj71.v14i1.190.

Watt, Esti Christina, dan Ivone Bonyadone Palar. "Tindakan Preventif Orang Tua Terhadap Pergaulan Bebas di Kalangan Remaja Kristen Suatu Pengamatan di GKII Efata Airmadi di Manado." Jurnal Jaffray 10, no. 2 (1 Oktober 2012): 140-56. https://doi.org/10.25278/jj71.v10i2.56.

Wenas, Maria Lidya, dan I Putu Ayub Darmawan. "Siginifikasi Pendidikan Anak Dalam Perspektif Alkitab." Evangelikal: Jurnal Teologi Injili dan Pembinaan Warga Jemaat 1, no. 2 (2 Agustus 2017): 118-28.

Wijaya, Etistika Yuni, Dwi Agus Sudjimat, dan Amat Nyoto. "Transformasi Pendidikan Abad 221 Sebagai Tuntutan Pengembangan Sumber Daya Manusia di Era Global." Dalam Prosiding Seminar Nasional Pendidikan Matematika 2016 - Universitas Kanjuruhan Malang, 1:263-78. Malang: Universitas Kanjuruhan Malang, 2016. Yang, Ferry. Pendidikan Kristen. Surabaya: Momentum, 2018. 